\title{
Pharmacists' Knowledge and Perceptions of Emergency Contraceptive Pills in Soweto and the Johannesburg Central Business District, South Africa
}

By Kelly Blanchard, Teresa Harrison and Mosala Sello

Kelly Blanchard is president, and

Teresa Harrison is project manager, Ibis Reproductive Health, Cambridge, MA, USA. Mosala

Sello is a consultant with the Population Council, Johannesburg, South Africa.
CONTEXT: In South Africa, emergency contraceptive pills are available directly from pharmacies without a prescription, yet few studies have assessed pharmacists' knowledge of and attitudes toward the medication.

METHODS: In-person interviews were conducted with 34 pharmacists practicing in Soweto and the Johannesburg Central Business District, from February through April 2003. The pharmacists provided data on their knowledge of emergency contraceptive pills and their attitudes toward providing the medication to women in specific situations.

RESULTS: Nearly all pharmacists sold at least one of the two types of dedicated emergency contraceptive pills available in South Africa. Although most had accurate knowledge about the method's dosing schedule, side effects and mechanism(s) of action, more than half erroneously believed that repeated use posed health risks. A large majority of pharmacists believed the pills should be available to rape victims, to single or married women and to women who had never given birth, but almost half did not think the pills should be given to women younger than 18, and a fourth said they would not give them to women with a late menstrual period. About one-third to half of pharmacists supported advance provision of the medication under certain circumstances. Most were willing to display promotional materials on emergency contraceptives in their pharmacies.

CONCLUSIONS: Interventions aimed at educating pharmacists about the benefits of emergency contraceptive pills, especially for adolescents, are needed. Government and medical authorities should take advantage of pharmacists' willingness to display educational materials as a way to increase women's knowledge and use of the medication in South Africa.

International Family Planning Perspectives, 2005, 31(4):172-178
Emergency contraceptive pills contain either progestin alone or a combination of estrogen and progestin in higher doses than regular oral contraceptives. If taken within 72 hours of unprotected intercourse, they can reduce a woman's risk of pregnancy by at least $75 \% .{ }^{1}$ They are safe and effective ${ }^{2}$ and, according to World Health Organization guidelines, the only contraindication to use is a confirmed pregnancy. ${ }^{3}$ The pills are not harmful to a pregnant woman or her fetus, and they will not terminate a pregnancy. Women taking these pills will sometimes experience short-term nausea and vomiting, ${ }^{4}$ neither of which poses a significant health risk. Even with repeated use, women would be exposed to lower hormone levels than if they used regular birth control pills, which themselves have an excellent safety profile. ${ }^{5}$

Although an estimated 76 million unintended pregnancies occur every year in developing countries, ${ }^{6}$ research on the global demand and need for emergency contraceptive pills is scant. The consequences of these pregnancies, particularly where abortion is legally restricted, may be lifethreatening. ${ }^{7}$ To lower rates of unintended pregnancy, women need better access to both regular contraceptive methods and emergency contraceptive pills.

Pharmacy provision of these pills could increase access by eliminating the barriers associated with obtaining a prescription from a health care provider within 72 hours of un- protected intercourse. ${ }^{8}$ Although recent research has shown that emergency contraceptive pills are still effective when taken up to 120 hours after unprotected intercourse, ${ }^{9}$ other research has indicated that the sooner they are taken, the better they work. ${ }^{10}$ For some women, getting a prescription and locating a provider quickly enough may be difficult or impossible, particularly on holidays or weekends. Forty-two percent of women in the U.S. state of California and 54\% in Canada who obtained the pills through pharmacy access programs purchased the method within 24 hours of contraceptive failure or unprotected intercourse, indicating that pharmacy provision allows for quick access to this time-sensitive medication. ${ }^{11}$ In four European countries where emergency contraceptive pills are available directly from pharmacists, women reported that such provision improved access to the method. ${ }^{12}$

According to the 1998 South Africa Demographic and Health Survey, $61 \%$ of sexually active women used a modern contraceptive method, yet $53 \%$ of all births were reported as mistimed or unwanted. Seventy-eight percent of births to women aged 19 or younger were unplanned. ${ }^{13}$ Furthermore, a 2004 UNAIDS/World Health Organization report estimated that about one in five adults in South Africa are infected with HIV. ${ }^{14}$ Condoms are the most effective method of preventing HIV and STI transmission, yet only 
6-16\% of women (depending on marital status) aged 15-49 reported condom use at last sexual intercourse. ${ }^{15}$ The use of emergency contraceptives as a backup for condom failure is an important option for women, and may encourage safer sexual behavior. A study from Mexico showed that use of emergency contraceptives was significantly associated with an increased probability of condom use at last sexual intercourse among adolescents. ${ }^{16}$ Two U.S. studies found that women may be more inclined to use condoms if emergency contraceptives are readily available. ${ }^{17}$

In 2000, the South Africa Medicines Control Council reclassified emergency contraceptive pills so that pharmacies could sell them without a prescription. Two dedicated products, one a combination of estrogen and progestin (E-GenC) and the other containing progestin only (NorLevo), were available in South Africa at the time of this study. Emergency contraceptives are also available free of charge at public health facilities, where staff typically "make their own" by providing pills from regular oral contraceptive packets.

Several studies have examined pharmacists' knowledge of and attitudes toward emergency contraceptives. The largest survey conducted in South Africa suggested that pharmacists in Durban were moderately knowledgeable about emergency contraception. ${ }^{18}$ Most pharmacists accurately described side effects and dosing requirements, but many inaccurately identified contraindications and expressed concern about repeat use. A separate analysis using the same sample revealed that pharmacists believed that greater access to emergency contraceptives would promote promiscuity, increase the incidence of STIs and decrease the use of barrier methods. ${ }^{19}$ However, these data were collected prior to the legalization of pharmacist provision of emergency contraceptives in South Africa, which likely led to increased familiarity with the medications.

Among drug store personnel in Thailand, where emergency contraceptives are available over the counter and where nonpharmacists are allowed to dispense medications, overall knowledge and provision of the method were found to be poor. ${ }^{20}$ Knowledge of timing and indications for use, as well as quality of service, were better in pharmacist-owned drugstores than in stores owned by nonpharmacists. Widespread misinformation about dosing among drug store personnel was likely due in part to incorrect product leaflet information.

A study of pharmacists in the U.S. state of Pennsylvania, where the method is available only by prescription, found that one-third of them knew the time limit for initiating emergency contraceptive pills; almost half correctly identified nausea and vomiting as side effects, and a small proportion believed that the pills caused abortions. ${ }^{21}$ Multivariate analysis showed that more accurate knowledge was a strong predictor of whether pharmacists stocked emergency contraceptives.

Our study assessed pharmacists' knowledge and perceptions of emergency contraceptive pills in two urban areas of Johannesburg two years after the method became available without a prescription in the nation's pharmacies.

\section{METHODS}

Between February and April 2003, we conducted a census of all pharmacies in Soweto and the Johannesburg Central Business District. We identified 55 pharmacies through the local pharmacy association, telephone books and word of mouth from other pharmacists. We visited each pharmacy to determine eligibility for the study; criteria included providing retail pharmacy services and being located in the study area. Fifteen pharmacies were not eligible: Twelve did not exist or did not operate in the area, two were wholesalers and did not serve the public and one was not a licensed pharmacy.

At the 40 eligible pharmacies, all of which provided family planning products, head pharmacists or pharmacy owners were asked if they were interested in participating in a study of pharmacists' knowledge and provision of family planning methods. Twelve declined to participate because of time constraints, leaving 28 pharmacies in our sample. We asked them to identify all pharmacists and assistant pharmacists who provided medications; in most cases, the owner or head pharmacist was the only eligible respondent. When more than one individual provided services, all were invited to participate. We interviewed 34 individuals in 28 pharmacies: two pharmacists in six stores and one in each of the remaining 22 stores. One pharmacist completed only a partial interview. By law, and in practice, only registered pharmacists and assistant pharmacists may dispense medications and counsel clients in South Africa, so we did not interview other staff. We visited each pharmacy an average of four times before an interview was conducted (range, one to six times); each interview lasted 45-60 minutes.

We adapted a questionnaire used in studies of knowledge and provision of emergency contraceptives in Mexico and Kenya. ${ }^{22}$ We chose questions that were appropriate for pharmacists in South Africa, and pretested the questionnaire with two pharmacists working in stores outside the study area. All interviews were conducted by a trained interviewer. The questionnaire, which included both closedand open-ended questions, covered demographic characteristics and professional background, and knowledge of the dosing schedules, side effects, mechanisms of action, contraindications and effectiveness of emergency contraceptive pills. We elicited their opinions on supplying emergency contraceptives (at need or in advance) to women in specific situations - having a late menstrual period or having been raped-or on the basis of such personal characteristics as age, marital status and having had children. They were also asked whether their pharmacy did or would be willing to display promotional materials for emergency contraceptives. Finally, we asked pharmacists about stocking and sales of the medication in their stores.

The data were checked for completeness and accuracy, and then coded for analysis by the second author. We used SPSS version 11.5 to calculate proportions. Because this study was designed to be a descriptive assessment of pharmacists' knowledge and attitudes, we did not conduct tests of significance. 
TABLE 1. Number of participating pharmacists, by demographic and professional characteristics, Soweto and Johannesburg Central Business District, South Africa, 2003

\begin{tabular}{lc} 
Characteristic & No. \\
\hline Age & \\
$20-29$ & 11 \\
$30-39$ & 10 \\
$40-49$ & 6 \\
$\geq 50$ & 6 \\
Gender & \\
Male & 20 \\
Female & 14 \\
& \\
Race & \\
African & 22 \\
White & 5 \\
Indian & 4 \\
Coloured/other & 2 \\
Pharmacist training & \\
Pharmacy diploma or degree & \\
Pharmacist assistance course & 24 \\
Yrs. of pharmacist experience & 10 \\
$1-5$ & \\
$6-10$ & \\
$11-20$ & 11 \\
$21-30$ & 8 \\
$31-50$ & 5 \\
Registered with national pharmacist association & \\
Yes & 29 \\
No & 3 \\
Trained in family planning & 5 \\
Yes & \\
No & \\
Trained in emergency contraceptives & 13 \\
Yes & 21 \\
No & \\
\hline Note: Ns may not total 34 because of nonresponse for some items. & 16 \\
& \\
\hline
\end{tabular}

\section{RESULTS}

\section{Characteristics}

The mean age of respondents was 38 (range, 22-66 years); the majority were male (20) and African (22-Table 1). Of the 34 respondents, 24 were head pharmacists with a diploma or bachelor's degree in pharmacy and 10 were assistant pharmacists. More than half (19) had worked as a pharmacist for 10 or fewer years, and most were registered with the national pharmacist association. Only 13 had training in family planning, and 16 had specific training in emergency contraceptives. Of this latter group, nine had been trained during university studies, three had attended a session given by the pharmaceutical society and four had attended a session organized by their employer, a pharmaceutical sales representative or the department of health. Their average family planning client was 30 or younger, had a secondary education and earned less than R1,000 per month (about US\$150).

\section{Knowledge of Emergency Contraceptives}

All respondents had heard of emergency contraceptive pills; the majority had first learned about them at university, or in a pharmacy or hospital (Table 2). Most pharmacists knew that the pills should be taken within 72 hours of unprotected intercourse. Most also correctly identified nausea and vomiting as possible side effects, and knew that the method worked by inhibiting ovulation, fertilization or implantation. More than half of respondents mentioned pregnancy as a contraindication; a similar proportion considered emergency contraceptives to be "effective," and one-third reported that effectiveness was $50-100 \%$. Six in 10 respondents believed that taking the pills more than once posed health risks to women. Only two pharmacists incorrectly described the medication as an abortifacient.

\section{Perceptions of Emergency Contraceptives}

In general, respondents viewed emergency contraceptive pills as an effective option for women who want to avoid unintended pregnancy. The majority of pharmacists believed the pills should be provided to women who were nulliparous, single or married, as well as to rape victims (Table 3). Fewer than half thought the pills were appropriate for women younger than 18 , and a quarter felt the method was appropriate for women with a late menstrual period.

About one-third of respondents reported that they did not offer emergency contraceptives to minors (not shown). Several pharmacists said that use of the pills promoted promiscuity and repeat use, and increased the risk of contracting HIV and other STIs. One commented that the method "encourages people not to use precautions... [and to overlook] the spread of STIs like HIV/AIDS."

Pharmacists' attitudes regarding advance provision of emergency contraceptives were less favorable than for general provision of the medication. Nonetheless, a majority approved of their provision to married and single women, although smaller proportions approved of advance provision to nulliparous women or women younger than 18. Respondents who disapproved of advance provision said they were concerned that having an advance supply would en-

\begin{tabular}{|lc|} 
TABLE 2. Number of pharmacists, by source of knowledge \\
about emergency contraceptive pills, and by accurate \\
knowledge and misperceptions regarding the pills \\
Characteristic & No. \\
\hline Source & \\
University & 16 \\
Pharmacy or hospital & 12 \\
Peers or workshop & 4 \\
Advertisement or customers & 1 \\
Do not know & 1 \\
& \\
Accurate knowledge & \\
Dosing schedule & $30^{*}$ \\
Side effects & $28^{*}$ \\
Mechanism(s) of action & $27^{*}$ \\
Contraindication & $19^{*}$ \\
Effectiveness & 16 \\
$\quad$ Effective (nonspecific) & 11 \\
50-100\% & 7 \\
Other & \\
Misperceptions & $20^{*}$ \\
Repeat use is a health risk & 2 \\
Pills act as an abortifacient & \\
\hline *One pharmacist did not respond to these questions. &
\end{tabular}


TABLE 3. Number of pharmacists who believed that emergency contraceptive pills should be provided to women with specific characteristics, by type of provision

Characteristic

No.

\section{General provision}

Rape victim

Married

Single

Nulliparous

$<18$ yrs. old

Late menstrual period

Advance provision

Married

Single

Nulliparous

$<18$ yrs. old

Note: One pharmacist did not complete this part of the interview.

courage women to use the pills as a regular form of contraception and would reduce the likelihood of their using condoms for protection against HIV and STIs.

Nearly all of the pharmacists sold at least one of the two dedicated products available in South Africa, with two-thirds selling both brands (not shown). Only two respondents did not carry either product. One did not stock the pills for religious reasons, but was willing to order the method on request. Another did not stock or sell them because his staff was not yet trained, although he anticipated selling dedicated emergency contraceptive products in the near future.

Most of the pharmacists had begun selling emergency contraceptives in the five years prior to being interviewed; the great majority of this group reported that customer demand had prompted them to stock the method (not shown). A few respondents said that the policy change to make the pills available in pharmacies without a prescription had encouraged them to start selling the medication. Only one pharmacist disagreed with the policy, claiming that it promoted promiscuity and unsafe sex.

\section{Provision of Information}

One-fifth of the pharmacists provided clients with written materials on emergency contraceptives, and nearly two-thirds counseled clients on pregnancy prevention (e.g., by promoting condom use or a regular form of contraception-not shown). Almost one-third of pharmacists offered educational materials on prevention of HIV and other STIs, and more than three-quarters reported offering HIV and STI counseling. Pharmacists thought the best ways to distribute information about emergency contraceptives were through media advertisements, patient education and pamphlets. Four out of five were willing to display promotional materials. A few said that counseling clients at pharmacies and antenatal clinics would be an effective means of disseminating information.

\section{DISCUSSION}

Pharmacists in Soweto and the Johannesburg Central Business District were familiar with emergency contraceptive pills. Nearly half had learned about the method while at university, suggesting that some formal academic training was available, though not required. A large proportion of pharmacists were knowledgeable about its dosing schedule, side effects and mechanism(s) of action, with fewer providing correct information on contraindications and effectiveness. Limited knowledge about contraindications, however, is not necessarily a cause for concern. Pregnancy is the only contraindication, and even if a pregnant woman took the medication, there is no evidence to suggest it would harm her or her fetus. ${ }^{23}$ Pharmacists did not appear to restrict access to the method because of misperceptions about contraindications.

Nearly all pharmacists reported selling emergency contraceptives, and most attributed this decision to customer demand. The large number of customer requests reported elsewhere in South Africa suggests that pharmacists in urban areas perceive customer demand to be substantial. ${ }^{24}$ There are, however, no public statistics to determine actual demand, and research conducted among South African women indicates that knowledge and use of emergency contraceptives are limited. ${ }^{25}$ Furthermore, pharmacists' knowledge about the pills may play an indirect role in their likelihood of stocking and selling the method. For example, well-informed pharmacists in the United States are more likely to carry the medication. ${ }^{26}$

All but two of the pharmacists in our study supported pharmacy provision of emergency contraceptives, and most viewed the method as an important pregnancy prevention option for women. Yet despite these generally positive perceptions, a substantial number of pharmacists did not believe them to be appropriate, either on demand or in advance, for women younger than 18 , and admitted denying minors access to the method. Other studies have shown that it is not uncommon for health care providers to impose age restrictions that deny young women access to hormonal contraceptives. ${ }^{27}$ The high rate of teenage pregnancy in South Africa provides evidence that adolescents need greater access to emergency contraceptives. Incorporating information about the public health benefits, particularly for adolescents, into pharmacists' family planning training could help to change attitudes and improve the availability of these contraceptives.

Most pharmacists in our study mistakenly believed that repeated use of emergency contraceptive pills was associated with health risks. Although the available evidence indicates that repeated use is safe, ${ }^{28}$ this concern has been expressed by health professionals in a wide range of settings. ${ }^{29}$ Such misperceptions are one reason some pharmacists are reluctant to provide the pills to women who need them on multiple occasions. Moral objections have also been shown to result in limited provision of emergency contraceptives. ${ }^{30}$ However, only two respondents said they believed the pills acted as an abortifacient, and one of them nonetheless sold the medication.

Pharmacists also expressed concern that increased access to the method encouraged unprotected sexual intercourse or reduced routine contraceptive use. Research in a variety of contexts has shown that expanded access does 
not increase the rate of unprotected sexual intercourse, nor does it change sexual behavior. ${ }^{31}$ The unfounded belief that greater access results in risky sexual practices could be a barrier to pharmacists' willingness to provide emergency contraceptives in advance of need, particularly for young women. In South Africa, where knowledge of emergency contraception is limited and unintended pregnancy rates are high, interventions that encourage pharmacists to provide pills in advance would likely increase women's use of the medication.

Pharmacists should be encouraged to counsel clients on both the use of emergency contraceptives and the prevention of HIV and STIs, particularly since the method can be promoted as a complement to condom use. Given the extent of the HIV epidemic in South Africa, use of condoms is extremely important. Ironically, few pharmacists offered counseling on condom use or ongoing contraception for pregnancy prevention, despite the fact that women who need emergency contraceptives have had unprotected intercourse or experienced a contraceptive failure. Since condom use appears to be increasing in South Africa, pharmacists could distribute materials to condom buyers that promote emergency contraceptives as a back-up method of contraception.

This study has several limitations. The survey was conducted in two areas within greater metropolitan Johannesburg, and although we conducted a census of all pharmacies in these areas, the results may not be generalizable to Johannesburg or to the rest of South Africa. In addition, pharmacists who refused to participate in the survey may be less likely to provide emergency contraceptives. However, we have no reason to believe that the data are not generalizable to other pharmacists in the same urban area. Another limitation is that we relied on pharmacists' self-reports rather than pharmacy sales records for information on stocking and sales of emergency contraceptives. These data are less accurate and pharmacists might have overreported the availability of emergency contraceptives. In designing future studies, researchers should consider interviewing pharmacy clients and collecting sales data from store records in addition to surveying pharmacists.

\section{Conclusion}

Pharmacists in Soweto and the Johannesburg Central Business District were generally knowledgeable about emergency contraceptive pills and perceived them to be an important option for preventing unintended pregnancies. Although some pharmacists reported unwarranted fears about health risks and increases in unprotected sex, and thus greater exposure to HIV and STIs, these misperceptions did not appear to prevent them from selling the medication. Restricted access for teenagers, however, is a barrier to wider use. Government and medical authorities should take advantage of pharmacists' expressed willingness to display promotional materials to increase women's knowledge and use of emergency contraceptives. By providing information on emergency contraception to their clients, pharmacists could play a significant role in raising women's awareness of the method in South Africa, and thereby make an invaluable contribution to public health.

\section{REFERENCES}

1. Trussell J, Rodríguez G and Ellertson C, Updated estimates of the effectiveness of the Yuzpe regimen of emergency contraception, Contraception, 1999, 59(3):147-151

2. Turner AN and Ellertson C, How safe is emergency contraception? Drug Safety, 2002, 25(10):695-706; and Food and Drug Administration, Prescription drug products: certain combined oral contraceptives for use as postcoital emergency contraception, Federal Register, 1997, 62(37):8610-8612.

3. World Health Organization (WHO), Emergency Contraception: A Guide for Service Delivery, Geneva: WHO, 1998.

4. Trussell J, Ellertson C and Stewart F, The effectiveness of the Yuzpe regimen of emergency contraception, Family Planning Perspectives, 1996, 28(2):58-64.

5. Kubba AA, Contraception: a review, International Journal of Clinical Practice, 1998, 52(2):102-105; and Shulman LP, Oral contraceptives: risks, Obstetrics and Gynecology Clinics of North America, 2000, 27(4):695-704.

6. Singh S et al., Adding It Up: The Benefits of Investing in Sexual and Reproductive Health Care, New York: The Alan Guttmacher Institute and UNFPA, 2003

7. WHO, Reduction of maternal mortality, a joint WHO/UNFPA/ UNICEF/World Bank statement, Geneva: WHO, 1999.

8. Glasier A and Baird D, The effects of self-administering emergency contraception, New England Journal of Medicine, 1998, 339(1):1-4; Ellertson C et al., Emergency contraception: a review of the programmatic and social science literature, Contraception, 2000, 61(3):145-186; and Bissell P and Anderson C, Supplying emergency contraception via community pharmacies in the UK: reflections on the experiences of users and providers, Social Science $\varepsilon$ Medicine, 2003, 57(12):2367-2378.

9. Ellertson C et al., Extending the time limit for starting the Yuzpe regimen of emergency contraception to 120 hours, Obstetrics $\mathcal{E}$ Gynecology, 2003, 101(6):1168-1171.

10. Task Force on Postovulatory Methods of Fertility Regulation, Randomised controlled trial of levonorgestrel versus the Yuzpe regimen of combined oral contraceptives for emergency contraception, Lancet, 1998, 352(9126):428-433.

11. Boggess JE, How can pharmacies improve access to emergency contraception? Perspectives on Sexual and Reproductive Health, 2002, 34(3):162-165; and Dunn S et al., Pharmacy provision of emergency contraception: the Ontario emergency contraception pilot project, Journal of Obstetrics and Gynaecology Canada, 2003, 25(11): 923-930.

12. Gainer E et al., Bringing emergency contraception over the counter: experiences of nonprescription users in France, Norway, Sweden and Portugal, Contraception, 2003, 68(2):117-124.

13. Department of Health of South Africa, Medical Research Council and Macro International, South Africa Demographic and Health Survey 1998, Preliminary Report, Pretoria, South Africa: Department of Health, 1999

14. UNAIDS/WHO Working Group on Global HIV/AIDS and STI Surveillance, Epidemiological fact sheets on HIV/AIDS and sexually transmitted infections, South Africa, 2004 update, <http://www. who.int/GlobalAtlas/predefinedReports/EFS2004/EFS_PDFs/ EFS2004_ZA.pdf>, accessed Mar. 19, 2005.

15. Department of Health of South Africa, Medical Research Council and Macro International, 1999, op. cit. (see reference 13).

16. Walker DM et al., Emergency contraception use is correlated with increased condom use among adolescents: results from Mexico, Journal of Adolescent Health, 2004, 35(4):329-334.

17. Roye CF, Routine provision of emergency contraception to teens and subsequent condom use: a preliminary study, letter to the ed- 
itor, Journal of Adolescent Health, 2001, 28(3):165-166; and Gold MA et al., The effects of advance provision of emergency contraception on adolescent women's sexual and contraceptive behaviors, Journal of Pediatric and Adolescent Gynecology, 2004, 17(2):87-96.

18. Hariparsad N, Knowledge of emergency contraception among pharmacists and doctors in Durban, South Africa, European Journal of Contraception and Health Care, 2001, 6(1):21-26.

19. Hariparsad N, Attitudes and practices of pharmacists towards emergency contraception in Durban, South Africa, European Journal of Contraception and Health Care, 2001, 6(1):87-92.

20. Ratanajamit $C$ and Chongsuvivatwong V, Survey of knowledge and practice on oral contraceptive and emergency contraceptive pills of drugstore personnel in Hat Yai, Thailand, Pharmacoepidemiology and Drug Safety, 2001, 10(2):149-156.

21. Bennett W et al., Pharmacists' knowledge and the difficulty of obtaining emergency contraception, Contraception, 2003, 68(4):261267.

22. Langer A et al., Emergency contraception in Mexico City: what do health care providers and potential users know and think about it? Contraception, 1999, 60(4):233-241; and Muia E et al., Emergency contraception in Nairobi, Kenya: knowledge, attitudes and practices among policymakers, family planning providers and clients, and university students, Contraception, 1999, 60(4):223-232.

23. WHO, 1998, op. cit. (see reference 3).

24. Hariparsad N, 2001, op. cit. (see reference 18).

25. Ehlers VJ, Adolescent mothers' utilization of contraceptive services in South Africa, International Nursing Review, 2003, 50(4):229241; and Smit J et al., Emergency contraception in South Africa: knowledge, attitudes and use among public sector primary healthcare clients, Contraception, 2001, 64(6):333-337.

26. Bennett W et al., 2003, op. cit. (see reference 21).

27. Miller Ket al., eds., Clinic-Based Family Planning and Reproductive Health Services in Africa: Findings from Situation Analysis Studies, New York: Population Council, 1998; Muia E et al., 1999, op. cit. (see reference 22); and Conard LA et al., Pharmacists' attitudes toward and practices with adolescents, Archives of Pediatrics and Adolescent Medicine, 2003, 157(4):361-364.

28. WHO, 1998, op. cit. (see reference 3); Abuabara K et al., As often as needed: appropriate use of emergency contraceptive pills, Contraception, 2004, 69(4):339-342.

29. Hariparsad N, 2001, op. cit. (see reference 18); Langer A et al., 1999, op. cit. (see reference 22); Gold M, Schein A and Coupey SM, Emergency contraception: a national survey of adolescent health experts, Family Planning Perspectives, 1997, 29(1):15-19; and Golden $\mathrm{NH}$ et al., Emergency contraception: pediatricians' knowledge, attitudes, and opinions, Pediatrics, 2001, 107(2):287-292.

30. Golden NH et al., 2001, op. cit. (see reference 29).

31. Glasier A and Baird D, 1998, op. cit. (see reference 8); Jackson R et al., Advance supply of emergency contraception: effect on use and usual contraception - a randomized trial, Obstetrics \& Gynecology, 2003, 102(2):8-16; Raine TR et al., Direct access to emergency contraception through pharmacies and effect on unintended pregnancies and STIs, Journal of the American Medical Association, 2005, 293(1):54-62; Lovvorn A et al., Provision of emergency contraceptive pills to spermicide users in Ghana, Contraception, 2000, 61(4): 287-293; and Raine T et al., Emergency contraception: advance provision in a young, high-risk clinic population, Obstetrics $\&$ Gynecology, 2000, 96(1):1-7.

\section{RESUMEN}

Contexto: En Sudáfrica, las píldoras anticonceptivas de emergencia se pueden adquirir sin receta médica directamente en las farmacias; no obstante, pocos estudios han evaluado el nivel de conocimientos de los farmacéuticos y sus actitudes con respecto a este medicamento.

Métodos: Desde febrero hasta abril de 2003 se realizaron en- trevistas personales a 34 farmacéuticos en Soweto y en el Distrito Comercial Central de Johannesburgo. Éstos suministraron datos acerca de su conocimiento de las píldoras anticonceptivas de emergencia y sobre sus actitudes con respecto a suministrar este medicamento a mujeres en situaciones específicas.

Resultados: Casi todos los farmacéuticos habian vendido por lo menos uno de los dos regímenes de píldoras anticonceptivas de emergencia disponibles en Sudáfrica. Si bien la mayoría tenía conocimientos adecuados acerca de las dosis, la forma de uso de este medicamento, y sus efectos secundarios y mecanismo (s) de acción, más de la mitad creía, equivocadamente, que su uso repetitivo presentaba riesgos a la salud. La gran mayoría de los farmacéuticos creían que las píldoras deberían estar a la disposición de las víctimas de violación, de las mujeres solteras o casadas, y de las que nunca habian dado a luz, aunque casi la mitad de los farmacéuticos no consideraban que se les debería expender este medicamento a mujeres menores de 18 años. La cuarta parte de los farmacéuticos indicaron que no entregarían estas píldoras a las mujeres que tuvieran un período menstrual tardío. Entre un tercio y la mitad de los farmacéuticos apoyaron la idea de suministrar este medicamento con antelación, en determinadas circunstancias. La mayoría estaban dispuestos a colocar en sus farmacias afiches u otro tipo de promoción de las pildoras anticonceptivas de emergencia.

Conclusiones: Es necesario realizar actividades dirigidas a instruir a los farmacéuticos acerca de los beneficios de las píldoras anticonceptivas de emergencia, especialmente con relación a las adolescentes. El gobierno y las autoridades del sector de salud deberían aprovechar la disposición de los farmacéuticos para difundir material educativo y de promoción como una forma de incrementar el conocimiento de las mujeres con respecto al uso de este medicamento en Sudáfrica.

\section{RÉSUMÉ}

Contexte: En Afrique du Sud, la contraception d'urgence est accessible directement en pharmacie, sans ordonnance. Peu d'études ont cependant évalué les connaissances et les attitudes des pharmaciens à l'égard du traitement.

Méthodes: Des entrevues personnelles ont été menées avec 34 pharmaciens de Soweto et du centre des affaires de Johannesburg, de février à fin avril 2003. Les pharmaciens ont ainsi fourni les données relatives à leur connaissance de la contraception d'urgence et à leurs attitudes à l'égard de l'apport du traitement aux femmes dans des circonstances spécifiques.

Résultats: Presque tous les pharmaciens vendaient au moins un des deux produits de contraception d'urgence disponibles en Afrique du Sud. Si la plupart avaient une connaissance correcte du dosage, des effets secondaires et du ou des mécanismes d'action de la méthode, plus de la moitié pensaient erronément que l'usage répété posait des risques pour la santé. Une grande majorité de pharmaciens estimaient que la contraception d'urgence devrait être disponible aux victimes de viol, aux femmes célibataires ou mariées et aux femmes qui n'ont pas encore eu d'enfants, mais près de la moitié ne pensaient pas qu'il devrait l'être aux femmes de moins de 18 ans et un quart ont déclaré qu'ils ne le donneraient pas en cas de retard des règles. Entre tiers environ et la moitié des pharmaciens étaient favorables à 
la fourniture anticipée du médicament dans certaines circonstances. La plupart étaient disposés à présenter un matériel promotionnel sur la contraception d'urgence dans leur pharmacie. Conclusions: Des interventions destinées à éduquer les pharmaciens sur les avantages de la contraception d'urgence, pour les adolescentes surtout, sont nécessaires. Les autorités gouvernementales et médicales devraient tirer parti de la disposition des pharmaciens à présenter un matériel éducatif pour accroître la sensibilisation et le recours des femmes au médicament en Afrique du Sud.

\section{Acknowledgments}

Charlotte Ellertson and Kate Miller provided comments on an early draft of this article. The research was funded by the Tides Foundation.

Author contact: tharrison@ibisreproductivehealth.org 